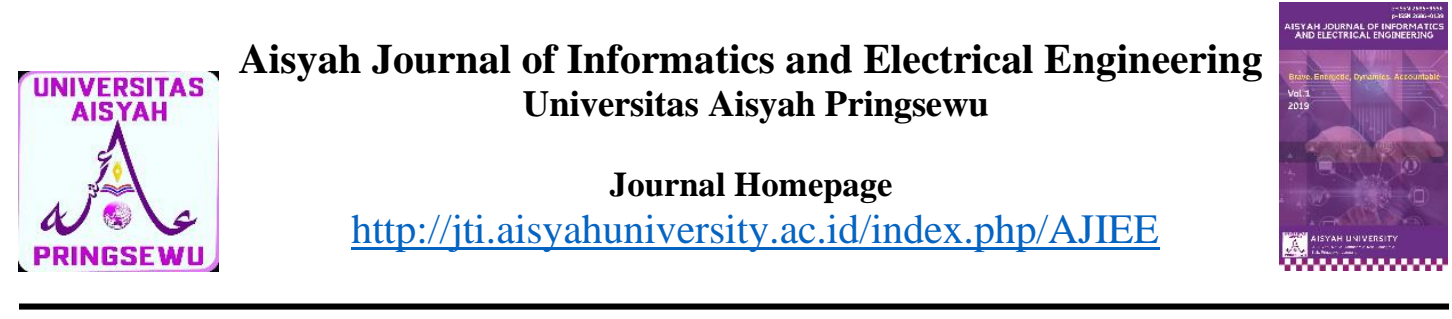

\title{
ANALISIS PEMBIAYAAN PRODUKTIF PADA BANK BTPN SYARIAH MENGGUNAKAN METODE AHP DAN TOPSIS "STUDI KASUS : PT. BANK BTPN SYARIAH LAMPUNG TENGAH"
}

\author{
Nuri Safitri \\ Magister Teknik Informatika, Ilmu Komputer \\ Institut Informatika Dan Bisnis Darmajaya Bandar Lampung \\ Nurisafitri1990@gmail.com
}

\begin{abstract}
This research was made based on the needs of the manager sentra in determining the priorities of productive financing at BTPN Syariah banks in central lampung. Appropriate decisions related to it, is one of the determining factors in maintaining the health of banks. Prioritization of productive financing, based on five criteria variable, and this research indicate that the priority of productive financing can be determined through Analitycal Hierarchy Process (AHP) method and Technique for Order Preference by Similirarity to Ideal Solution (TOPSIS) method. AHP method is used to find the weight of criteria variables, character, capacity, condition, basic information, status, while TOPSIS is used to find the final score and the rank of each alternatives. Result of this research indicate that the utility of AHP and TOPSIS method as a decision support system model that can help manager sentra of BTPN Syariah Central Lampung, and based on through the test results by comparing the system output before and after the resulting correlation coefficient of 0.975 and a significant value of 0.004 .
\end{abstract}

Keywords: Financing Analysis, AHP, TOPSIS

\begin{abstract}
ABSTRAK
Penelitian ini dibuat didasarkan pada kebutuhan manager sentra dalam menentukan prioritas pembiayaan produktif pada bank BTPN Syariah di Lampung Tengah. Keputusan yang tepat terkait hal tersebut merupakan salah satu faktor penentu dalam menjaga tingkat kesehatan bank. Penentuan prioritas pembiayaan produktif didasarkan melalui lima variabel kriteria, dan dalam penelitian ini menunjukkan bahwa prioritas pembiayaan produktif dapat ditentukan melalui penggunakan metode Analitycal Hierarchy Process (AHP) dan metode Technique for Order Preference by Similirarity to Ideal Solution (TOPSIS). Metode AHP digunakan untuk mencari bobot variabel kriteria character, capacity, condition, basic information, status, sedangkan TOPSIS digunakan untuk mencari nilai akhir dan perangkingan. Dari hasil penelitian ini menunjukkan manfaat dari metode AHP dan TOPSIS sebagai model sistem pendukung keputusan yang dapat membantu manager sentra BTPN Syariah Lampung Tengah, dimana melalui hasil pengujian dengan membandingkan output sistem sebelum dan sesudah dihasilkan koefisien korelasi sebesar 0.975 dan nilai significant sebesar 0.004.
\end{abstract}

Kata Kunci: Analisis Pembiayaan, AHP, TOPSIS 


\section{PENDAHULUAN}

\subsection{Latar Belakang}

Di Indonesia, terdapat dua jenis lembaga perbankan yaitu perbankan konvensional dan perbankan syariah. Dalam Undang-undang no. 21 Tahun 2008 tentang perbankan syariah dikatakan "bahwa perbankan syariah memiliki kekhususan dibandingkan dengan perbankan konvensional". yaitu dalam pelaksanaan operasionalnya perbankan syariah menggunakan prinsip-prinsip syariah Islam, dan tidak menjalankan sistem bunga . Bank Indonesia memperkenalkan sebuah peraturan nomor 14/22/PBI/2012 dan revisinya nomor 17/12/PBI/2015 yang mewajibkan pemberian kredit oleh bank umum kepada usaha-usaha mikro, kecil, menengah (UMKM), peraturan ini tentunya sangat bermanfaat untuk membantu usaha-usaha kecil mendapatkan pembiayaan yang sangat mereka butuhkan. BTPN Syariah berperan penting dalam membantu memberikan pembiayaan dalam bentuk usaha mikro dimana target nya adalah para pengusaha mikro dan fokus memberikan pembiayaan khususnya kepada kaum perempuan dari segmen prasejahtera produktif. Pada kenyataanya penulis telah melihat khususnya masyarakat yang ada di daerah Lampung Tengah, yang terletak di Jl. AH nasution kel yosorejo Metro Timur. Bank BTPN Syariah ini memiliki 8 MMS (Mobile Marketing Syariah). Satu diantaranya MMS Rumbia selama ini proses pengajuan pembiayaan dilakukan dengan menuliskan hasil data survey tersebut kedalam form LSWAP. Secara prinsip, BTPN Syariah menggunakan 5 kriteria, yaitu riwayat pembiayaan, installment income ratio (IIR), usaha yang dibiayai, kehadiran, status kepemilikan tempat tinggal. Walaupun 5 kriteria sudah cukup lengkap sebagai acuan dalam pertimbangan untuk memberikan pembiayaan Namun dalam prakteknya sering mempertimbangkan faktor lain yang diperlukan misalnya seorang nasabah mungkin saja faktor Character nya cocok untuk diberikan kredit, tetapi faktor Capacity nya belum mencukupi. Karena itu, dikembangkan kriteria dan sub kriteria lanjutan sesuai kondisi lapangan yang terjadi pada pihak bank yang diteliti. Kriteria dan sub kriteria yang dikembangkan lebih lanjut yaitu character ( riwayat pembiayaan, penggunaan dana komunitas, sikap, penilaian warga lingkungan), capacity ( Installment Income Ratio, sisa penghasilan, penghasilan keluarga, saldo tabungan), condition ( usaha yang dibiayai, lama usaha, jangka waktu pembiayaan, usia), basic information ( pendidikan, jumlah tanggungan, kehadiran, kelengkapan dokumen ), status ( status rumah, lama menempati, status tempat usaha, status perkawinan). Metode yang digunakan dalam penelitian ini adalah metode Analytical Hierarchy Process (AHP) dan Technique for Order by Similarity to Ideal Solution (TOPSIS). Metode AHP digunakan untuk mencari bobot variabel kriteria character, capacity, condition, basic information dan status. Sedangkan metode TOPSIS digunakan untuk menentukan nilai akhir dan perangkingan.

Aisyah Journal of Informatics and Electrical Engineering 
Penggabungan metode AHP dan TOPSIS bertujuan untuk meningkatkan performansi dari metode TOPSIS, karena penggunaan metode TOPSIS memerlukan bobot awal untuk pengolahan data selanjutnya. Sedangkan metode AHP dipilih karena AHP membandingkan antar variabel kriteria, menentukan bobot kepentingan dari setiap kriteria berdasarkan pertimbangan semua kriteria terkait dan akan menghasilkan nilai prioritas dari tertinggi hingga terendah, sehingga resiko ketidaktepatan dalam pembobotan pada metode TOPSIS berkurang dengan penggunaan metode AHP. Artikel ini merupakan hasil dari penelitian penulis sendiri sehingga artikel ini murni gagasan, rumusan dan penelitian melalui proses bimbingan dan pengujian.

\section{TINJAUAN PUSTAKA}

\subsection{Sistem pendukung keputusan}

Sistem Pendukung Keputusan merupakan suatu sistem informasi berbasis computer yang dirancang sedemikian rupa untuk membantu pengguna dalam memilih salah satu dari banyak solusi alternatif dari suatu masalah. (Tripathi, 2011)

\subsubsection{Tahapan Pengambilan Keputusan}

Proses pengambilan keputusan melalui beberapa tahap sebagai berikut (Eniyati,2011)

a. Tahap Penulusuran (Intelegence) dilakukan pencarian prosedur, pengumpulan data, identifikasi masalah, b. Tahap Perancangan (Design)

Merancang model yang akan digunakan dan kriteria - kriteria yang ditentukan. Setelah itu dicari alternatif model yang bisa menyelesaikan permasalahan tersebut.

c. Tahap Pemilihan (Choice)

Pada tahapan ini akan dilakukan pemilihan modelnya termasuk solusi dari model tersebut

d. Tahap Implementasi (implementation)

Dari tahap ini didapatkan laporan pelaksanaan solusi dan hasilnya.

\subsubsection{Konsep Dasar Multi-Atribut Decision Making (MADM)}

Multi-criteria decision making (MCDM) adalah suatu metode pegambilan keputusan untuk menetapkan alternative terbaik dari sejumlah alternatif berdasarkan beberapa criteria tertentu.

\subsubsection{Analitycal Hierarchy Process}

(AHP)

AHP digunakan untuk memecahkan suatu situasi yang komplek tidak terstruktur kedalam beberapa komponen dalam susunan yang hirarki, dengan memberi nilai subjektif tentang pentingnya setiap variabel secara relatif, dan menetapkan variabel mana yang memiliki prioritas paling tinggi guna mempengaruhi hasil pada situasi tersebut. prinsip yang harus dipahami (Kusrini, 2007), diantaranya adalah :

1.Mendefinisikan masalah dan menentukan solusi yang diinginkan, lalu menyusun hierarki

Aisyah Journal of Informatics and Electrical Engineering 
2.Menentukan prioritas elemen dengan membandingkan elemen secara berpasangan sesuai dengan kriteria yang diberikan. Adapun tabel yang digunakan dalam menilai perbandingan pasangan adalah sebagai beikut :

Tabel 2.1.Skala penilaian perbandingan pasangan

\begin{tabular}{|c|c|}
\hline $\begin{array}{c}\text { Intensitas } \\
\text { Kepentingan }\end{array}$ & Keterangan \\
\hline 1 & $\begin{array}{l}\text { Kedua elemen } \\
\text { sama pentingnya }\end{array}$ \\
\hline 3 & $\begin{array}{l}\text { Elemen yang satu } \\
\text { cukup penting dari } \\
\text { pada elemen yang } \\
\text { lain }\end{array}$ \\
\hline 5 & $\begin{array}{l}\text { Elemen yang satu } \\
\text { lebih penting dari } \\
\text { elemen yang } \\
\text { lainnya }\end{array}$ \\
\hline 7 & $\begin{array}{l}\text { Elemen yang satu } \\
\text { jelas lebih penting } \\
\text { daripada elemen } \\
\text { lainnya }\end{array}$ \\
\hline 9 & $\begin{array}{l}\text { Satu elemen } \\
\text { mutlak penting } \\
\text { daripada elemen } \\
\text { lainnya }\end{array}$ \\
\hline $2,4,6,8$ & $\begin{array}{l}\text { Nilai-nilai antara } \\
\text { dua nilai } \\
\text { pertimbangan } \\
\text { pertimbangan yang } \\
\text { berdekatan }\end{array}$ \\
\hline Kebalikan & $\begin{array}{l}\text { Jika aktivitas i } \\
\text { mendapat satu } \\
\text { angka } \\
\text { dibandingkan } \\
\text { dengan aktivitas j, } \\
\text { maka j memiliki } \\
\text { nilai kebalikan } \\
\text { dibandingkan i }\end{array}$ \\
\hline
\end{tabular}

3.Synthesis of priority (menentukan prioritas) dengan Menjumlahkan nilai-nilai dari setiap kolom pada matriks, kemudian Membagi setiap nilai dari kolom dengan total kolom yang bersangkutan untuk memperoleh normalisasi matriks lalu Menjumlahkan nilai-nilai dari setiap baris dan membaginya dengan jumlah elemen untuk mendapatkan nilai rata-rata

4. Mengukur konsistensi

$$
\begin{aligned}
& \mathrm{CI}=\frac{\propto \max -\mathrm{n}}{\mathrm{n}-1} \\
& \mathrm{n}=\text { banyaknya elemen } \\
& \propto=\text { jumlahkan hasil bagi dengan } \\
& \text { banyaknya elemen }
\end{aligned}
$$

5. Menghitung Consistency Ratio (CR) dengan rumus:

$$
\begin{aligned}
& \mathrm{CR}=\frac{\mathrm{CI}}{\mathrm{CR}} \\
& \mathrm{CR}=\text { Consistency Ratio } \\
& \mathrm{CI}=\text { Consistency Index } \\
& \mathrm{IR}=\text { Indeks Random Consistency }
\end{aligned}
$$

Tabel 2.2. Daftar Indeks Random Konsistensi

\begin{tabular}{|c|c|}
\hline Ukuran Matriks & Nilai IR \\
\hline 1,2 & 0,00 \\
\hline 3 & 0,58 \\
\hline 4 & 0,90 \\
\hline 5 & 1,12 \\
\hline 6 & 1,24 \\
\hline 7 & 1,32 \\
\hline 8 & 1,41 \\
\hline 9 & 1,45 \\
\hline 10 & 1,49 \\
\hline 11 & 1,51 \\
\hline \multicolumn{2}{|l}{} \\
\hline
\end{tabular}




\begin{tabular}{|l|l|}
\hline 12 & 1,48 \\
\hline 13 & 1,56 \\
\hline 14 & 1,57 \\
\hline 15 & 1,59 \\
\hline
\end{tabular}

\subsubsection{Technique For Others Reference By Similarity To Ideal Solution (TOPSIS)}

TOPSIS menggunakan prinsip bahwa alternatif yang terpilih harus mempunyai jarak terdekat dari solusi ideal positif dan terjauh dari solusi ideal negatif dari sudut pandang geometris dengan menggunakan jarak Euclidean untuk menentukan kedekatan relatif dari suatu alternatif dengan solusi optimal. Adapun langkahlangkah algoritma dari TOPSIS ini adalah sebagai berikut (Indira, 2012) :

1. Membuat matriks keputusan alternatif

$$
\begin{aligned}
& \mathrm{r}_{\mathrm{ij} j}=\frac{\mathrm{x}_{\mathrm{ij}}}{\sqrt{\sum_{i=1}^{m} x_{i j}^{2}}} \quad \begin{array}{l}
\mathrm{i}=1,2, \ldots, \mathrm{m} \\
\mathrm{j}=1,2, \ldots, \mathrm{n}
\end{array} \\
& \mathrm{r}_{\mathrm{ij}}=\text { matriks norma: } \\
& \mathrm{x}_{\mathrm{ij}}=\text { matriks keputusan }
\end{aligned}
$$

2. Menghitung matriks keputusan yang Ternormalisasi Terbobot

$$
\begin{aligned}
\mathrm{v}_{\mathrm{ij}}= & \mathrm{W}_{\mathrm{j}} * \mathrm{r}_{\mathrm{ij}} \\
& \text { dimana } \\
& \text { wj merupakan bobot dari kriteria }
\end{aligned}
$$$$
\text { ke-j }
$$

3. Menentukan solusi ideal positif $\left(\mathrm{A}^{+}\right)$dan solusi ideal negatif $\left(\mathrm{A}^{-}\right)$

$$
\begin{aligned}
& \mathrm{A}^{+}=\left(\mathrm{v}_{1}^{+}+, \mathrm{v}_{2}^{+}+\mathrm{v}_{3}^{+}, \ldots, \mathrm{v}_{\mathrm{n}}^{+}\right) \\
& \mathrm{A}^{-}=\left(\mathrm{v}_{1}^{-}+, \mathrm{v}_{2}^{-}+\mathrm{v}_{3}^{-}, \ldots, \mathrm{v}_{\mathrm{n}}^{-}\right)
\end{aligned}
$$

Dengan $\mathrm{vj}^{+}=$

$\left\{\max _{\mathrm{j}} \mathrm{j}_{\mathrm{j} j} \mathrm{jika} \mathrm{j}\right.$ adalah atribut keuntungan

$\min _{\mathrm{j}} \mathrm{j}_{\mathrm{j} j} \mathrm{jika} \mathrm{j}$ adalah atribut biaya

$\mathrm{vj}^{-}=$

$\left\{\min _{\mathrm{j}} \mathrm{j}_{\mathrm{j} j} \mathrm{jika} \mathrm{j}\right.$ adalah atribut keuntungan

$\max _{\mathrm{i}} \mathrm{j}_{\mathrm{j} j} \mathrm{jika} \mathrm{j}$ adalah atribut biaya

$$
\mathrm{j}=1,2, \ldots, \mathrm{n}
$$

4. Menentukan jarak antara setiap alternative dengan solusi ideal positif dan solusi ideal negative. Jarak antara alternatif dengan solusi ideal positif $\left(\mathrm{D}_{\mathrm{i}}{ }^{+}\right)$dan jarak antara alternatif dengan solusi ideal negatif $\left(\mathrm{D}_{\mathrm{i}^{-}}\right)$dirumuskan:

$\mathrm{D}_{\mathrm{i}}^{+}=\sqrt{\left.\sum_{\mathrm{j}=1}^{\mathrm{n}} \mathrm{V}_{\mathrm{ij}}-\mathrm{V}_{\mathrm{j}}^{+}\right)^{2}}$

Dengan $\mathrm{i}=1,2, \ldots, \mathrm{m}$

$D_{i}^{-}=\sqrt{\sum_{j=1}^{n}\left(V_{i j}-V_{j}^{-}\right)^{2}}$

Dengan $\mathrm{i}=1,2, \ldots, \mathrm{m}$

5. Menghitung nilai kedekatan relatif yang merupakan nilai preferensi untuk setiap alternative

$$
\mathrm{V}_{\mathrm{i}}=\frac{\mathrm{D}_{\mathrm{i}}^{-}}{\mathrm{D}_{\mathrm{i}}^{-}+\mathrm{D}_{\mathrm{i}}^{+}}
$$

Dengan $\mathrm{i}=1,2, \ldots, \mathrm{m}$

\subsection{Penelitian Terkait}

1.Pada penelitian sebelumnya menurut irawan wingdes (2017) dengan menggunakan AHP TOPSIS, unsur subjektifitas dapat dibobot dan dikalkulasi sehingga keputusan lebih objektif dan terukur pada penyaluran kredit mobil di BPR Centradana Kapuas Pontianak.

2.Penelitian menurut Nelly Astuti Hasibuan, LinceTomoria Sianturi, Ronda Deli Sianturi, Suhastra Indrawan (2016 ) dihasilkan suatu sistem yang dapat

Aisyah Journal of Informatics and Electrical Engineering 
membantu pihak Bank dalam menentukan siapa yang layak menerima Kredit Usaha Rakyat (KUR), sehingga dapat lebih efisien dalam pelaksanaannya.

3.Penelitian menurut Yustinus Zai, Mesran, Berto Nadeak, Imam Saputra (2017) dalam mencari alternatif calon nasabah terbaik bedasarkan kriteria-kriteria yang telah ditentukan dengan mengggunakan metode TOPSIS untuk menghitung kelayakan dari calon nasabah.

\section{METODOLOGI}

\subsection{Alur penelitian}

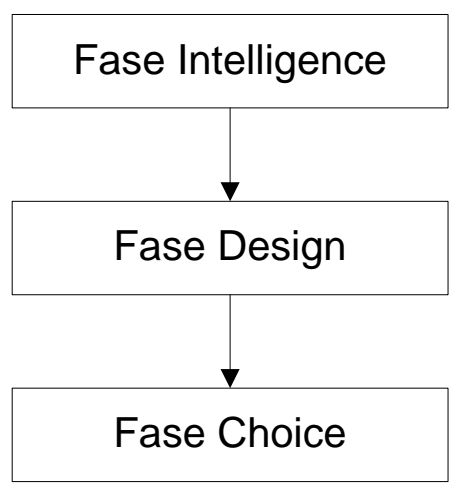

Gambar 3.1 Alur Penelitian

\subsection{Fase Penulusuran (intelligence)}

\section{Metode Pengumpulan Data}

1. Data primer

a. Metode wawancara

Metode wawancara dilakukan kebagian analisis pembiayaan syariah sesuai dengan kebutuhan penelitian mengenai proses pengajuan dalam pengambilan keputusan pembiayaan di bank BTPN Syariah dan kriteria-kriteria yang digunakan untuk menentukan pembiayaan kepada nasabah. b. Metode observasi

Observasi dilakukan dengan cara melakukan pengamatan secara langsung kepada objek yang diteliti sehingga dapat dipahami cara kerja sistem yang berjalan.

2. Data Sekunder

a. Studi dokumentasi

Studi dokumentasi digunakan untuk mencari data-data sekunder yang dibutuhkan dalam menentukan item-item yang akan dipakai.

b. Akses internet

Digunakan untuk mencari data-data pendukung dari berbagai buku maupun jurnal

c. Studi yang relevan

Studi relevan ini digunakan sebagai acuan dalam melakukan penelitian yang didasarkan pada karya-karya ilmah yang memiliki nilai kesamaan dengan isi atau kasus yang sedang dilakukan.

\subsection{Fase Design}

\section{Kriteria Penelitian}

Tabel 3.1. kriteria dan sub kriteria pembiayaan produktif

\begin{tabular}{|c|l|l|}
\hline \multicolumn{2}{|c|}{ Kriteria } & Kode \\
\hline \multirow{4}{*}{ kriteria Utama } & character & C1 \\
\cline { 3 - 4 } & capacity & C2 \\
\cline { 3 - 4 } & condition & C3 \\
\cline { 3 - 4 } & $\begin{array}{l}\text { basic } \\
\text { information }\end{array}$ & $\mathrm{C} 4$ \\
\cline { 3 - 4 } $\begin{array}{c}\text { Sub } \\
\text { Kriteria }\end{array}$ & Status & C5 \\
\hline \multirow{4}{*}{ Character } & $\begin{array}{l}\text { riwayat } \\
\text { pembiayaan }\end{array}$ & C11 \\
\cline { 3 - 4 } & $\begin{array}{l}\text { penggunaan } \\
\text { dana } \\
\text { komunitas }\end{array}$ & C12 \\
\cline { 3 - 4 } & sikap & $\mathrm{C} 13$ \\
\hline
\end{tabular}

57

Aisyah Journal of Informatics and Electrical Engineering 


\begin{tabular}{|c|c|c|}
\hline & $\begin{array}{l}\text { penilaian } \\
\text { warga } \\
\text { lingkungan }\end{array}$ & $\mathrm{C} 14$ \\
\hline \multirow{4}{*}{ Capacity } & $\begin{array}{l}\text { installment } \\
\text { income ratio } \\
\text { (IIR) }\end{array}$ & $\mathrm{C} 21$ \\
\hline & $\begin{array}{l}\text { sisa } \\
\text { penghasilan }\end{array}$ & $\mathrm{C} 22$ \\
\hline & $\begin{array}{l}\text { penghasilan } \\
\text { keluarga }\end{array}$ & $\mathrm{C} 23$ \\
\hline & $\begin{array}{l}\text { saldo } \\
\text { tabungan }\end{array}$ & $\mathrm{C} 24$ \\
\hline \multirow{4}{*}{ Condition } & $\begin{array}{l}\text { usaha yang } \\
\text { dibiayai }\end{array}$ & C31 \\
\hline & lama usaha & C32 \\
\hline & $\begin{array}{l}\text { jangka } \\
\text { waktu } \\
\text { pembiayaan }\end{array}$ & C33 \\
\hline & Usia & C34 \\
\hline \multirow{4}{*}{$\begin{array}{c}\text { Basic } \\
\text { Information }\end{array}$} & pendidikan & $\mathrm{C} 41$ \\
\hline & $\begin{array}{l}\text { jumlah } \\
\text { tanggungan }\end{array}$ & $\mathrm{C} 42$ \\
\hline & kehadiran & $\mathrm{C} 43$ \\
\hline & $\begin{array}{l}\text { kelengkapan } \\
\text { dokumen }\end{array}$ & $\mathrm{C} 44$ \\
\hline \multirow{4}{*}{ Status } & $\begin{array}{l}\text { status } \\
\text { rumah }\end{array}$ & C51 \\
\hline & $\begin{array}{l}\text { lama } \\
\text { menempati }\end{array}$ & C52 \\
\hline & $\begin{array}{l}\text { status } \\
\text { tempat } \\
\text { usaha } \\
\end{array}$ & $\mathrm{C} 53$ \\
\hline & $\begin{array}{l}\text { status } \\
\text { perkawinan }\end{array}$ & C54 \\
\hline
\end{tabular}

\section{Tahap penelitian}

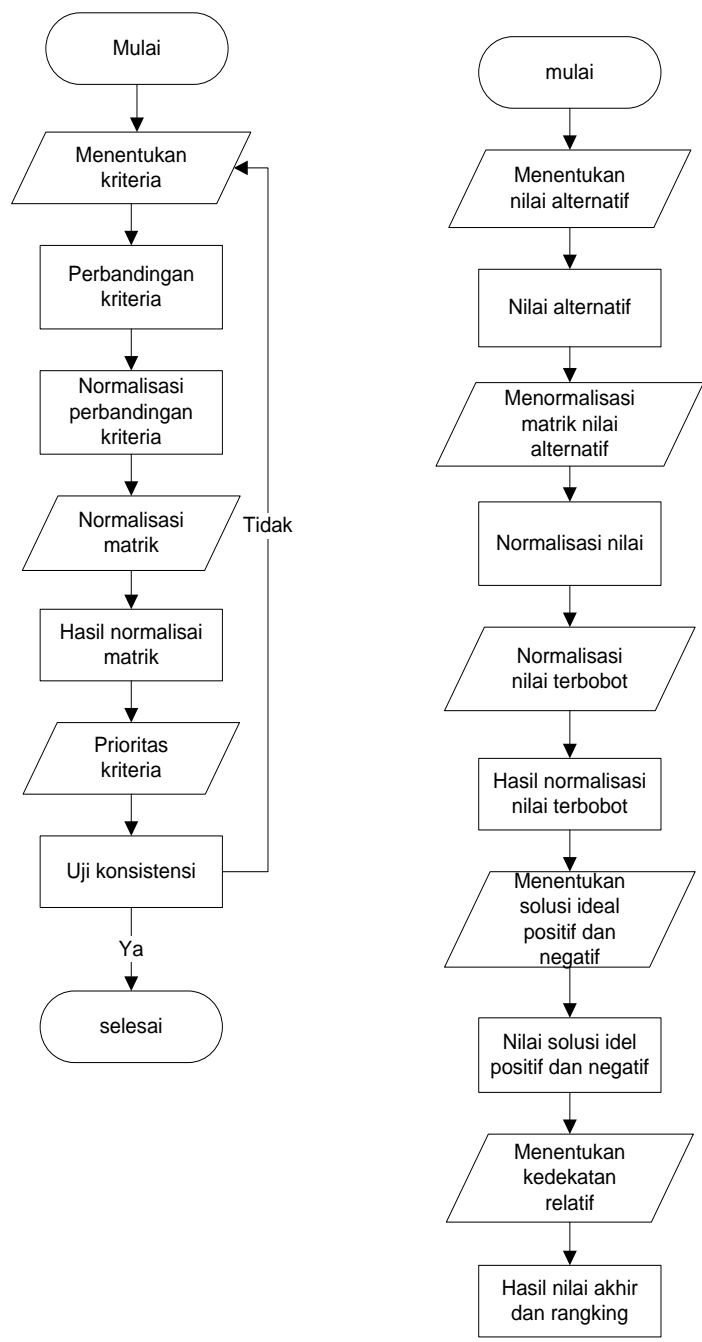

\section{Gambar 3.2. Tahapan AHP TOPSIS}

\section{HASIL DAN PEMBAHASAN}

\subsection{Bobot kepentingan kriteria dan Subkriteria AHP}

Perbandingan berpasangan dilakukan untuk proses AHP, nilai perbandingan dari lima kriteria dan dua puluh sub kriteria didapat dari kuisioner yang diberikan kepada manager sentra BTPN Syariah, dan hasil perbandingan, normalisasi dan 
konsistensi dapat dilihat pada table dibawah ini

Table 4.1. matrik perbandingan, normalisasi, konsistensi kriteria utama

\begin{tabular}{|c|c|c|c|c|c|c|}
\hline kriteria & $\mathrm{C} 1$ & $\mathrm{C} 2$ & $\mathrm{C} 3$ & $\mathrm{C} 4$ & $\mathrm{C} 5$ & $\mathrm{EV}$ \\
\hline $\mathrm{C} 1$ & 1.00 & 2.00 & 2.00 & 4.00 & 5.00 & 0.38 \\
\hline $\mathrm{C} 2$ & 0.50 & 1.00 & 2.00 & 3.00 & 5.00 & 0.27 \\
\hline $\mathrm{C} 3$ & 0.50 & 0.50 & 1.00 & 3.00 & 4.00 & 0.20 \\
\hline $\mathrm{C} 4$ & 0.25 & 0.33 & 0.33 & 1.00 & 2.00 & 0.09 \\
\hline $\mathrm{C} 5$ & 0.20 & 0.20 & 0.25 & 0.50 & 1.00 & 0.05 \\
\hline total & 2.45 & 4.03 & 5.58 & 11.50 & 17.00 & 1.00 \\
\hline $\mathrm{CI}$ & \multicolumn{7}{|c|}{0.02} \\
\hline IR & \multicolumn{7}{|c|}{0.02} \\
\hline CR & \multicolumn{7}{|c|}{} \\
\hline
\end{tabular}

Table 4.2. matrik perbandingan, normalisasi, konsistensi kriteria character

\begin{tabular}{|c|c|c|c|c|c|}
\hline $\mathrm{C} 1$ & $\mathrm{C} 11$ & $\mathrm{C} 12$ & $\mathrm{C} 13$ & $\mathrm{C} 14$ & $\mathrm{EV}$ \\
\hline $\mathrm{C} 11$ & 1.00 & 2.00 & 2.00 & 3.00 & 0.41 \\
\hline $\mathrm{C} 12$ & 0.50 & 1.00 & 2.00 & 3.00 & 0.29 \\
\hline $\mathrm{C} 13$ & 0.50 & 0.50 & 1.00 & 2.00 & 0.18 \\
\hline $\mathrm{C} 14$ & 0.33 & 0.33 & 0.50 & 1.00 & 0.10 \\
\hline total & 2.33 & 3.83 & 5.50 & 9.00 & 1.00 \\
\hline CI & \multicolumn{5}{|c|}{0.02} \\
\hline IR & \multicolumn{5}{|c|}{0.90} \\
\hline $\mathrm{CR}$ & \multicolumn{5}{|c|}{} \\
\hline
\end{tabular}

Table 4.3. matrik perbandingan, normalisasi, konsistensi kriteria capacity

\begin{tabular}{|c|c|c|c|c|r|}
\hline C2 & C21 & C22 & C23 & C24 & EV \\
\hline & 1.0 & 2.0 & 3.0 & 5.0 & 0.4 \\
C21 & 0 & 0 & 0 & 0 & 6 \\
\hline & 0.5 & 1.0 & 2.0 & 4.0 & 0.2 \\
C22 & 0 & 0 & 0 & 0 & 8 \\
\hline & 0.3 & 0.5 & 1.0 & 4.0 & 0.1 \\
C23 & 3 & 0 & 0 & 0 & 8 \\
\hline & 0.2 & 0.2 & 0.2 & 1.0 & 0.0 \\
C24 & 0 & 5 & 5 & 0 & 6 \\
\hline
\end{tabular}

\begin{tabular}{|c|c|c|c|c|c|} 
& 2.0 & 3.7 & 6.2 & 14. & \\
total & 3 & 5 & 5 & 0 & 1.00 \\
\hline CI & \multicolumn{5}{|c|}{0.03} \\
\hline IR & \multicolumn{5}{|c|}{0.90} \\
\hline CR & \multicolumn{5}{|c|}{0.03} \\
\hline
\end{tabular}

Table 4.4. matrik perbandingan, normalisasi, konsistensi kriteria condition

\begin{tabular}{|c|c|c|c|r|r|}
\hline C3 & C31 & C32 & C33 & C34 & EV \\
\hline & 1.0 & 4.0 & 3.0 & 2.0 & 0.4 \\
C31 & 0 & 0 & 0 & 0 & 6 \\
\hline & 0.2 & 1.0 & 0.5 & 0.3 & 0.0 \\
C32 & 5 & 0 & 0 & 3 & 9 \\
\hline & 0.3 & 2.0 & 1.0 & 0.5 & 0.1 \\
C33 & 3 & 0 & 0 & 0 & 6 \\
\hline & 0.5 & 3.0 & 2.0 & 1.0 & 0.2 \\
C34 & 0 & 0 & 0 & 0 & 7 \\
\hline & 2.0 & 10. & 6.5 & 3.8 & \\
total & 8 & 0 & 0 & 3 & 1.00 \\
\hline CI & \multicolumn{7}{|c|}{0.01} \\
\hline IR & \multicolumn{7}{|c|}{0.01} \\
\hline CR & \multicolumn{7}{|c|}{} \\
\hline
\end{tabular}

Table 4.5. matrik perbandingan, normalisasi, konsistensi kriteria basic information

\begin{tabular}{|c|c|c|c|c|r|}
\hline C4 & C41 & C42 & C43 & C44 & EV \\
\hline & 1.0 & 0.3 & 0.2 & 0.2 & 0.0 \\
C41 & 0 & 3 & 0 & 0 & 6 \\
\hline & 3.0 & 1.0 & 0.2 & 0.2 & 0.1 \\
C42 & 0 & 0 & 5 & 5 & 3 \\
\hline & 5.0 & 4.0 & 1.0 & 2.0 & 0.4 \\
C43 & 0 & 0 & 0 & 0 & 7 \\
\hline & 5.0 & 4.0 & 0.5 & 1.0 & 0.3 \\
C44 & 0 & 0 & 0 & 0 & 3 \\
\hline & 14. & 9.3 & 1.9 & 3.4 & \\
total & 0 & 3 & 5 & 5 & 1.00 \\
\hline CI & \multicolumn{5}{|c|}{0.05} \\
\hline IR & \multicolumn{7}{|c|}{0.06} \\
\hline CR & \multicolumn{7}{|c|}{} \\
\hline
\end{tabular}


Table 4.6. matrik perbandingan, normalisasi, konsistensi kriteria status

\begin{tabular}{|c|c|c|c|c|r|}
\hline C5 & C51 & C52 & C53 & C54 & EV \\
\hline & 1.0 & 4.0 & 3.0 & 5.0 & 0.5 \\
C51 & 0 & 0 & 0 & 0 & 4 \\
\hline & 0.2 & 1.0 & 0.5 & 2.0 & 0.1 \\
C52 & 5 & 0 & 0 & 0 & 4 \\
\hline & 0.3 & 2.0 & 1.0 & 2.0 & 0.2 \\
C53 & 3 & 0 & 0 & 0 & 1 \\
\hline & 0.2 & 0.5 & 0.5 & 1.0 & 0.0 \\
C54 & 0 & 0 & 0 & 0 & 9 \\
\hline & 1.7 & 7.5 & 5.0 & 10. & \\
total & 8 & 0 & 0 & 0 & 1.00 \\
\hline CI & \multicolumn{5}{|c|}{0.01} \\
\hline IR & \multicolumn{7}{|c|}{0.02} \\
\hline CR & \multicolumn{7}{|c|}{} \\
\hline
\end{tabular}

\begin{tabular}{|c|c|c|c|c|} 
A1 & 3 & 4 & 3 & 1 \\
\hline$A 2$ & 3 & 4 & 3 & 3 \\
\hline$A 3$ & 3 & 4 & 2 & 1 \\
\hline$A 4$ & 4 & 3 & 3 & 3 \\
\hline$A 5$ & 4 & 2 & 3 & 1 \\
\hline$A L T$ & $C 41$ & $C 42$ & $C 43$ & $C 44$ \\
\hline$A 1$ & 1 & 3 & 4 & 3 \\
\hline$A 2$ & 1 & 3 & 3 & 3 \\
\hline$A 3$ & 1 & 3 & 3 & 2 \\
\hline$A 4$ & 1 & 2 & 4 & 2 \\
\hline$A 5$ & 3 & 1 & 3 & 2 \\
\hline$A L T$ & $C 51$ & $C 52$ & $C 53$ & $C 54$ \\
\hline$A 1$ & 4 & 4 & 4 & 3 \\
\hline$A 2$ & 4 & 4 & 4 & 3 \\
\hline$A 3$ & 4 & 4 & 4 & 3 \\
\hline$A 4$ & 4 & 4 & 4 & 3 \\
\hline$A 5$ & 1 & 2 & 1 & 3 \\
\hline
\end{tabular}

\subsection{Perhitungan Menggunakan Topsis}

Table 4.8. Normalisasi matriks

\begin{tabular}{|c|c|c|c|c|}
\hline ALT & C11 & C12 & C13 & C14 \\
\hline A1 & 0.45 & 0.45 & 0.49 & 0.42 \\
\hline A2 & 0.45 & 0.45 & 0.37 & 0.42 \\
\hline A3 & 0.45 & 0.45 & 0.49 & 0.42 \\
\hline A4 & 0.45 & 0.45 & 0.37 & 0.55 \\
\hline A5 & 0.45 & 0.45 & 0.49 & 0.42 \\
\hline ALT & C21 & C22 & C23 & C24 \\
\hline A1 & 0.32 & 0.35 & 0.28 & 0.49 \\
\hline A2 & 0.48 & 0.35 & 0.28 & 0.49 \\
\hline A3 & 0.64 & 0.71 & 0.28 & 0.24 \\
\hline A4 & 0.48 & 0.35 & 0.28 & 0.49 \\
\hline A5 & 0.16 & 0.35 & 0.83 & 0.49 \\
\hline ALT & C31 & C32 & C33 & C34 \\
\hline A1 & 0.39 & 0.51 & 0.47 & 0.22 \\
\hline A2 & 0.39 & 0.51 & 0.47 & 0.65 \\
\hline A3 & 0.39 & 0.51 & 0.32 & 0.22 \\
\hline A4 & 0.52 & 0.38 & 0.47 & 0.65 \\
\hline
\end{tabular}

Tabel 4.7. skor pemohon kredit berdasarkan sub kriteria

\begin{tabular}{|c|c|c|c|c|}
\hline ALT & C11 & C12 & C13 & C14 \\
\hline A1 & 4 & 4 & 4 & 3 \\
\hline A2 & 4 & 4 & 3 & 3 \\
\hline A3 & 4 & 4 & 4 & 3 \\
\hline A4 & 4 & 4 & 3 & 4 \\
\hline A5 & 4 & 4 & 4 & 3 \\
\hline ALT & C21 & C22 & C23 & C24 \\
\hline A1 & 2 & 2 & 1 & 2 \\
\hline A2 & 3 & 2 & 1 & 2 \\
\hline A3 & 4 & 4 & 1 & 1 \\
\hline A4 & 3 & 2 & 1 & 2 \\
\hline A5 & 1 & 2 & 3 & 2 \\
\hline ALT & C31 & C32 & C33 & C34 \\
\hline
\end{tabular}

60

Aisyah Journal of Informatics and Electrical Engineering 


\begin{tabular}{|c|c|c|c|c|} 
A5 & 0.52 & 0.26 & 0.47 & 0.22 \\
\hline ALT & C41 & C42 & C43 & C44 \\
\hline A1 & 0.28 & 0.53 & 0.52 & 0.55 \\
\hline A2 & 0.28 & 0.53 & 0.39 & 0.55 \\
\hline A3 & 0.28 & 0.53 & 0.39 & 0.37 \\
\hline A4 & 0.28 & 0.35 & 0.52 & 0.37 \\
\hline A5 & 0.83 & 0.18 & 0.39 & 0.37 \\
\hline ALT & C51 & C52 & C53 & C54 \\
\hline A1 & 0.50 & 0.49 & 0.50 & 0.45 \\
\hline A2 & 0.50 & 0.49 & 0.50 & 0.45 \\
\hline A3 & 0.50 & 0.49 & 0.50 & 0.45 \\
\hline A4 & 0.50 & 0.49 & 0.50 & 0.45 \\
\hline A5 & 0.12 & 0.24 & 0.12 & 0.45 \\
\hline
\end{tabular}

\begin{tabular}{|c|c|c|c|c|} 
A4 & 0.02 & 0.05 & 0.24 & 0.12 \\
\hline A5 & 0.06 & 0.02 & 0.18 & 0.12 \\
\hline ALT & C51 & C52 & C53 & C54 \\
\hline A1 & 0.27 & 0.07 & 0.11 & 0.04 \\
\hline A2 & 0.27 & 0.07 & 0.11 & 0.04 \\
\hline A3 & 0.27 & 0.07 & 0.11 & 0.04 \\
\hline A4 & 0.27 & 0.07 & 0.11 & 0.04 \\
\hline A5 & 0.07 & 0.03 & 0.03 & 0.04 \\
\hline
\end{tabular}

Table 4.9. Ternormalisasi terbobot

\begin{tabular}{|c|c|c|c|c|}
\hline ALT & C11 & C12 & C13 & C14 \\
\hline A1 & 0.18 & 0.13 & 0.09 & 0.04 \\
\hline A2 & 0.18 & 0.13 & 0.07 & 0.04 \\
\hline A3 & 0.18 & 0.13 & 0.09 & 0.04 \\
\hline A4 & 0.18 & 0.13 & 0.07 & 0.06 \\
\hline A5 & 0.18 & 0.13 & 0.09 & 0.04 \\
\hline ALT & C21 & C22 & C23 & C24 \\
\hline A1 & 0.15 & 0.10 & 0.05 & 0.03 \\
\hline A2 & 0.22 & 0.10 & 0.05 & 0.03 \\
\hline A3 & 0.30 & 0.20 & 0.05 & 0.02 \\
\hline A4 & 0.22 & 0.10 & 0.05 & 0.03 \\
\hline A5 & 0.07 & 0.10 & 0.15 & 0.03 \\
\hline ALT & C31 & C32 & C33 & C34 \\
\hline A1 & 0.18 & 0.05 & 0.08 & 0.06 \\
\hline A2 & 0.18 & 0.05 & 0.08 & 0.18 \\
\hline A3 & 0.18 & 0.05 & 0.05 & 0.06 \\
\hline A4 & 0.24 & 0.04 & 0.08 & 0.18 \\
\hline A5 & 0.24 & 0.02 & 0.08 & 0.06 \\
\hline ALT & C41 & C42 & C43 & C44 \\
\hline A1 & 0.02 & 0.07 & 0.24 & 0.18 \\
\hline A2 & 0.02 & 0.07 & 0.18 & 0.18 \\
\hline A3 & 0.02 & 0.07 & 0.18 & 0.12 \\
\hline
\end{tabular}

Table 4.10. nilai preferensi alternatif

\begin{tabular}{|c|c|c|c|}
\hline ALT & $D^{+}$ & $D^{-}$ & $V$ \\
\hline A1 & 0.25 & 0.26 & 0.51 \\
\hline A2 & 0.19 & 0.31 & 0.61 \\
\hline A3 & 0.20 & 0.34 & 0.62 \\
\hline A4 & 0.18 & 0.31 & 0.63 \\
\hline A5 & 0.37 & 0.13 & 0.26 \\
\hline
\end{tabular}

\section{PENUTUP}

Berdasarkan pembahasan yang telah diuraikan, maka dapat disimpulkan Metode Analytical Hierarchy Process (AHP) digunakan untuk menentukan prioritas kriteria, sehingga dihasilkan nilai prioritas kriteria terbesar sampai terkecil. Setelah dilakukan pembobotan dengan AHP, maka dilakukan proses penghitungan rangking menggunakan TOPSIS sehingga di dapat skor penilaian. Berdasarkan simpulan yang ada maka penulis memiliki beberapa saran bahwa Pada penelitian selanjutnya dapat dikembangkan pengambilan keputusan berkelompok. Pembobotan dapat digunakan untuk penilaian kelompok sehingga pembuat keputusan utama mendapatkan bobot yang lebih besar serta dapat dilakukan dengan menambahkan kriteria agar mempertimbangkan faktor eksternal seperti hambatan - hambatan yang mungkin terjadi (constraint). Sehingga

61

Aisyah Journal of Informatics and Electrical Engineering 
akan menghasilkan keputusan yang lebih akurat lagi dan dapat dipergunakan sebagai referensi bagi peneliti selanjutnya.

\section{DAFTAR PUSTAKA}

[1] Tripathi, K. 2011. Decision Support System Is A Tool For Making Better Decisions In The Organization. India: Kolhapur

[2] Eniyati, Sri. 2011. Perancangan Sistem Pendukung Pengambilan Keputusan Untuk Penerimaan Beasiswa Dengan Metode SAW (Simple Additive Weighting). Jurnal Teknologi Informasi Dinamik Volume 16 No.2.171-176.

[3] Kursini. 2007. Konsep Dan Aplikasi Sistem Pendukung Keputusan Yogyakarta: CV.Andi Offset

[4] Indira. 2012. Seleksi Supplier Bahan Baku Dengan Metode Topsis Fuzzy MADM (Studi Kasus PT. Giri Sekar Kedaton,Gresik). Surabaya: Institut Teknologi Sepuluh November Surabaya

[5] Irawan Wingdes, Tri Widayanti, 2017. Penilaian Kelayakan Kredit Menggunakan AHP Dan TOPSIS.ISSN:1978-8282.BPR Centradana Kapuas.Pontianak

[6] Nelly Astuti Hasibuan, Lincetomoria Sianturi, Ronda Deli Sianturi, Suhastra Indrawan, 2016 Pemberian Pinjaman Kur Menggunakan AHP.Jurnal Riset Komputer (Jurikom), Vol. 3 No. 4 , ISSN 2407-389X. BRI. Medan

[7] Yustinus Zai, Mesran, Berto
Nadeak, Imam Saputra.2017 Pemberian Kredit Menggunakan Metode Topsis.Jurnal Informatika,Vol 1, No 1,ISSN 2548- 8368.PT SS Finance. Medan 